\title{
Assessment of Microbial Load in Raw Pork from Retail Meat Outlets of Bikaner
}

\author{
Pankaj Mangal*, Rakesh Rao and Rajani Joshi \\ Department of Veterinary Public Health, College of Veterinary and Animal Science, \\ RAJUVAS, Bikaner- 334001, Rajasthan, India \\ *Corresponding author
}

\section{A B S T R A C T}

\section{Keywords}

Pork, Standard plate count, Morbidity,

Mortality,

Foodborne infection

Article Info

Accepted:

04 January 2018

Available Online:

10 February 2018
Food-borne diseases are an important cause of morbidity and mortality worldwide. Most human diseases are shared with animals and food of animal origin is among the most important cause of gastro-intestinal diseases. Up to one-third of the population in developing countries is affected by foodborne diseases every year. Pork contains a high number of pathogenic bacteria such as Escherichia coli, nontyphoid Salmonella serovars and Staphylococcus aureus which remain a potential threat to human health and also serve as possible sources of infection. A wide range of possible microorganisms are transmitted by pork to human beings but fewer are likely to have a major impact on public health. In the present study, a total of 50 raw pork samples were collected from four private commercial enterprise retail meat outlets of Bikaner city and were evaluated for standard plate count. The mean standard plate count (SPC) for 50 raw pork samples was $1.51 \times 10^{6}$ $\mathrm{cfu} / \mathrm{gm}$ and maximum and minimum SPC values for the pork samples from the market to be $2.90 \times 10^{6} / \mathrm{gm}$ and $0.70 \times 10^{4} / \mathrm{gm}$, respectively.

\section{Introduction}

Domestication of pigs started somewhere around 5000 years ago. Pigs have great potential to fulfill demand of meat for increasing population of world because of their high feed conversion ratio, high prolific rate, short gestation period and great adaptability with respect to food and climate by Pond et al., (1991). Word 'pork has been derived from the French 'porc' and Latin 'porcus' meaning "pig". Pork has been proved to be an important source of food worldwide contributing about $40 \%$ to the total meat production around the world by Sherikar et al., (2013). Pork is the most perishable of all important foods since it contains sufficient nutrients needed to support the growth of microorganisms by Magnus (1981).

Sources for contamination of the pork can be abattoir, storage at the retailer's stall or shop, heavily contaminated utensils and benches used for the handling of pork.

Pork contamination occur by a variety of ways, including bowel rupture during evisceration, indirect contamination with tainted water and also handling and packaging of finished pork products. 
Foods of porcine origin are an important vehicle associated with development of antibiotic-resistant pathogens such as Salmonella spp., Escherichia coli, Yersinia spp., Staphylococci, Listeria monocytogenes by Wang et al., (2013). Isolates from retail pork in the last decade have shown a considerable increase in resistance against most antibiotics by Yucel et al., (2005).

Pork industry is in infancy in India. Due, to comparatively less consumption of pork most of the pig slaughtering is done as an unorganized sector. Such retailers have less knowledge about hygiene which can lead to cases of pork related food poisoning in the human subjects. Information and status of pork in relation to public health in this region is lacking.

\section{Materials and Methods}

The present study was conducted at the Department of Veterinary Public Health, College of Veterinary and Animal Science, Rajasthan University of Veterinary and Animal Sciences, Bikaner, India.

A total of 50 pork samples were collected for the present study from four retail meat outlets of Bikaner city. About 10-20 grams of pork samples were collected in sterilized test tubes and immediately brought to the laboratory under cold conditions. The samples were processed within 4-6 hours of collection. The Standard Plate Count (SPC) of pork samples was done by using pour plate method as described by Banwort (1989).

\section{Results and Discussion}

In the present study 50 raw pork samples were collected from four private commercial enterprise meat outlets of Bikaner city.

The mean standard plate count (SPC) was 1.51 x $10^{6} / \mathrm{gm}$ and maximum and minimum SPC values for the pork samples from the market to be $2.90 \times 10^{6} / \mathrm{gm}$ and $0.70 \times 10^{4} / \mathrm{gm}$, respectively (Table 1; Figure 1).

Prasad (1977) reported that the average total bacterial counts of ham samples were $3.7 \mathrm{x}$ $105 / \mathrm{gm}$ which was recorded less than present study. Murthy and Bachhil (1980) found that SPC/gm of fresh pork, first sign of off odors and clear spoilage of pork were $3.98 \times 10^{5} \pm$ $0.28,2.2 \times 10^{7} \pm 0.15$ and $1.2 \times 10^{7} / \mathrm{gm}$, respectively which showed that first one found less and last two showed more than this study.

Fig.1 Standard Plate Count (SPC) of raw pork samples

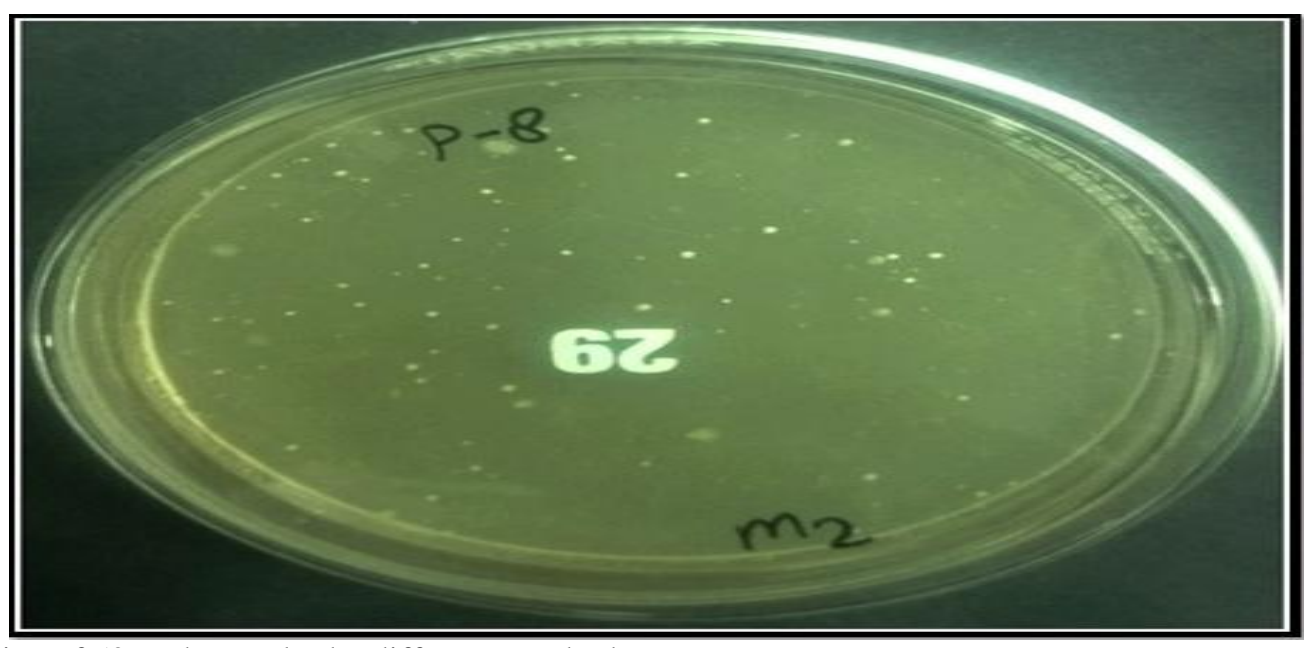


Table.1 Source of pork sample and their respective standard plate counts

\begin{tabular}{|c|c|c|c|}
\hline S. No. & Sample number & Source & SPC/gm of pork \\
\hline 01. & $\mathrm{P}-1$ & Ghanshyam Meat Centre & $0.9 \times 10^{5}$ \\
\hline 02. & P-2 & Rinku Meat Centre & $5.7 \times 10^{5}$ \\
\hline 03. & P-3 & Shubham Meat Centre & $5.9 \times 10^{5}$ \\
\hline 04. & $\mathrm{P}-4$ & Kishan Meat Centre & $1.8 \times 10^{6}$ \\
\hline 05. & P-5 & Ghanshyam Meat Centre & $1.9 \times 10^{5}$ \\
\hline 06. & P-6 & Rinku Meat Centre & $2.5 \times 10^{6}$ \\
\hline 07. & P-7 & Shubham Meat Centre & $2.2 \times 10^{6}$ \\
\hline 08. & P-8 & Kishan Meat Centre & $8.0 \times 10^{5}$ \\
\hline 09. & P-9 & Ghanshyam Meat Centre & $1.7 \times 10^{5}$ \\
\hline 10. & $\mathrm{P}-10$ & Rinku Meat Centre & $2.8 \times 10^{6}$ \\
\hline 11. & $\mathrm{P}-11$ & Shubham Meat Centre & $2.7 \times 10^{6}$ \\
\hline 12. & $\mathrm{P}-12$ & Kishan Meat Centre & $7.9 \times 10^{5}$ \\
\hline 13. & $\mathrm{P}-13$ & Ghanshyam Meat Centre & $0.8 \times 10^{5}$ \\
\hline 14. & P-14 & Shubham Meat Centre & $2.0 \times 10^{6}$ \\
\hline 15. & $\mathrm{P}-15$ & Rinku Meat Centre & $6.0 \times 10^{5}$ \\
\hline 16. & P-16 & Ghanshyam Meat Centre & $2.1 \times 10^{6}$ \\
\hline 17. & P-17 & Kishan Meat Centre & $2.7 \times 10^{6}$ \\
\hline 18. & P-18 & Shubham Meat Centre & $6.1 \times 10^{5}$ \\
\hline 19. & P-19 & Ghanshyam Meat Centre & $2.2 \times 10^{6}$ \\
\hline 20. & P-20 & Kishan Meat Centre & $2.3 \times 10^{6}$ \\
\hline 21. & $\mathrm{P}-21$ & Rinku Meat Centre & $1.1 \times 10^{5}$ \\
\hline 22. & $\mathrm{P}-22$ & Ghanshyam Meat Centre & $2.4 \times 10^{6}$ \\
\hline 23. & $\mathrm{P}-23$ & Shubham Meat Centre & $2.5 \times 10^{6}$ \\
\hline 24. & P-24 & Rinku Meat Centre & $2.9 \times 10^{6}$ \\
\hline 25. & P-25 & Kishan Meat Centre & $5.8 \times 10^{5}$ \\
\hline 26. & P-26 & Ghanshyam Meat Centre & $2.6 \times 10^{6}$ \\
\hline 27. & P-27 & Kishan Meat Centre & $2.6 \times 10^{6}$ \\
\hline 28. & P-28 & Shubham Meat Centre & $2.2 \times 10^{6}$ \\
\hline 29. & P-29 & Rinku Meat Centre & $8.1 \times 10^{4}$ \\
\hline 30. & P-30 & Ghanshyam Meat Centre & $7.0 \times 10^{5}$ \\
\hline 31. & P-31 & Kishan Meat Centre & $2.6 \times 10^{6}$ \\
\hline 32. & P-32 & Shubham Meat Centre & $2.0 \times 10^{6}$ \\
\hline 33. & P-33 & Rinku Meat Centre & $2.4 \times 10^{6}$ \\
\hline 34. & P-34 & Ghanshyam Meat Centre & $0.7 \times 10^{4}$ \\
\hline 35. & P-35 & Shubham Meat Centre & $7.4 \times 10^{5}$ \\
\hline 36. & P-36 & Shubham Meat Centre & $5.5 \times 10^{5}$ \\
\hline 37. & P-37 & Ghanshyam Meat Centre & $2.0 \times 10^{6}$ \\
\hline 38. & P-38 & Rinku Meat Centre & $2.1 \times 10^{6}$ \\
\hline 39. & P-39 & Kishan Meat Centre & $2.5 \times 10^{6}$ \\
\hline 40. & $\mathrm{P}-40$ & Shubham Meat Centre & $8.5 \times 10^{5}$ \\
\hline 41. & P-41 & Ghanshyam Meat Centre & $2.0 \times 10^{6}$ \\
\hline 42. & $\mathrm{P}-42$ & Rinku Meat Centre & $2.2 \times 10^{6}$ \\
\hline 43. & $\mathrm{P}-43$ & Shubham Meat Centre & $2.1 \times 10^{5}$ \\
\hline 44. & $\mathrm{P}-44$ & Kishan Meat Centre & $2.8 \times 10^{6}$ \\
\hline 45. & P-45 & Ghanshyam Meat Centre & $2.7 \times 10^{6}$ \\
\hline 46. & P-46 & Rinku Meat Centre & $7.1 \times 10^{5}$ \\
\hline 47. & P-47 & Kishan Meat Centre & $2.8 \times 10^{6}$ \\
\hline 48. & $\mathrm{P}-48$ & Ghanshyam Meat Centre & $1.4 \times 10^{5}$ \\
\hline 49. & P-49 & Shubham Meat Centre & $2.9 \times 10^{6}$ \\
\hline 50. & $\mathrm{P}-50$ & Rinku Meat Centre & $6.3 \times 10^{5}$ \\
\hline
\end{tabular}


Table.2 SPC of raw meat samples according to Goldenberg and Elliot (1973)

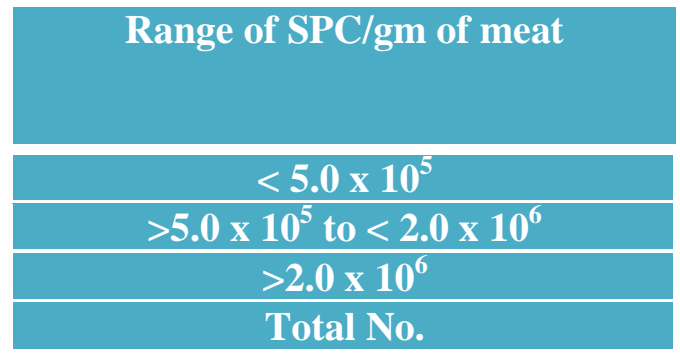

\begin{tabular}{|c|c|}
\hline Grade & $\begin{array}{c}\text { No }(\%) \text { of raw pork } \\
\text { samples collected from } \\
\text { various meat outlets }\end{array}$ \\
\hline Satisfactory & $8(16 \%)$ \\
\hline Acceptable & $15(30 \%)$ \\
\hline Rejected & $27(54 \%)$ \\
\hline
\end{tabular}

Table.3 SPC of raw meat samples according to ICMSF (1974)

\begin{tabular}{|c|c|c|}
\hline Range of SPC/gm of meat & Grade & $\begin{array}{c}\text { No }(\%) \text { of raw pork } \\
\text { samples collected from } \\
\text { various meat outlets }\end{array}$ \\
\hline$<1.0 \times 10^{5}$ & Acceptable & $4(8 \%)$ \\
\hline$>1.0 \times 10^{5}$ to $<1.0 \times 10^{6}$ & Marginally Acceptable & $18(36 \%)$ \\
\hline$>1.0 \times 10^{6}$ & Rejected & $28(56 \%)$ \\
\hline Total No. & & 50 \\
\hline
\end{tabular}

Table.4 SPC of raw meat samples according to BIS (1995)

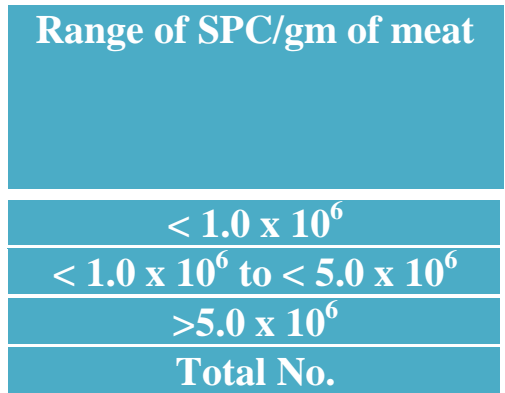

Borah et al., (1992) reported a maximum and minimum SPC values for the pork samples from the market to be $2.01 \mathrm{x} 10^{6} / \mathrm{gm}$ and $0.67 \mathrm{x}$ $10^{6} / \mathrm{gm}$, respectively that was found less than in maximum value. Whereas Singh et al., (2014) reported the mean value of SPC as $5.8 \times 10^{6} / \mathrm{gm}$ which was recorded more than present study.

Calderon et al., (1990) reported that the counts of mesophilic bacteria ranged from $5.4 \times 10^{4}$ to $6.7 \times 10^{7} / \mathrm{gm}$ which was higher than present study. Oliveria et al., (2002) found SPC for pork ranged from $4 \times 10^{2}$ to $7.3 \times 10^{5} / \mathrm{gm}$ reported less than present study further Greer et al., (2004) also found less standard plate count of boneless pork loins which was $1.8 \times 10^{5} / \mathrm{gm}$. Manguiat and Fang (2013) isolated the highest counts for aerobic plate count as $1.52 \times 10^{8} / \mathrm{gm}$ that suggested poor food hygiene practices and poor sanitation. Anachinaba et al., (2015) determined the standard plate count of pork samples ranged from $2.5 \times 10^{4} / \mathrm{gm}$ to $6.2 \mathrm{x}$ $10^{6} / \mathrm{gm}$ reported higher from present study (Table 2-4).

Such a high viable microbial load suggests practice of inadequate hygienic measures, mal handling and unhygienic condition of the retail shops.

\section{Acknowledgement}

We extend our sincere gratitude to dean, College of Veterinary and Animal Science, 
Rajasthan University of Veterinary and Animal Sciences, Bikaner-334001 for providing necessary facilities and funds to carry out this work.

\section{References}

Anachinaba IA, Adzitey F and Teye GA. 2015. Assessment of the Microbial Quality of Locally Produced Meat (Beef and Pork) in Bolgatanga Municipal of Ghana. International Journal of Food Safety. 17: 15.

Banwort GJ. 1989. Basic Food microbiology. In: Textbook of AVI Book Van Nostrand Reinhld, New York.

BIS. 1995. Indian standards of meat and meat products in mutton and goat meat (chevon)fresh, chilled and frozen technical requirements (First Revision), Bureau of Indian standards, New Delhi.

Borah P, Patgiri GP and Boro BR. 1992. Bacteriological quality of market pork in Guwahati city. Indian Veterinary Journal. 69: 773-775.

Calderon DF, Furlanetto SMP, Flores-Calderon D and Perrone-Furlanetto SM. 1990. Bacteriological analysis of pork sold in markets in the city of Saopaulo. Revista-deMicrobiologia. 21(4): 331-336.

Goldenberg N and Elliot DW. 1973. The value of agreed non agreed specification in the microbiological safety of food. Academic press, London, New York. 359-368.

Greer GG, Nattress F, Dilts B and Boker L. 2004. Studied the brine treated pork and boneless pork for microbial examination. Journal of Food production. 67(1): 185 - 188.

ICMSF. 1974. Micro-organisms in foods Vol. 2, University of Toronto Press, Toronto, Canada.

Magnus P. 1981. Meat Composition. Food
Science and Technology, $4^{\text {th }}$ edition, Gohumunary Pub. London. pp. 108-215.

Manguiat L S and Fang TJ. 2013. Microbiological quality of chicken- and pork-based streetvended foods from Taichung, Taiwan, and Laguna, Philippines. Food Microbiology. 36: 57-62.

Murthy TRK and Bachhil VN. 1980. Annual Report LPT Division, IVRI, Izatnagar.

Oliveira NO, Nascimento LC and Fiorini JE. 2002. The isolation and identification of mesophilic bacteria in fresh beef and pork. Higiene Alimentar. 16(94): 68-74.

Pond WG, Maner JH and Harris DL. 1991. The pig: past, present and future. Pork Production system. Van Nostrand Reinhold, New York. pp.12.

Prasad M. 1977. Studies on certain food poisoning bacteria of pork and pork products, P.G. thesis. Veterinary Public Health and Food Hygiene. 1: 56.

Sherikar AT, Bachhil VN and Thapliyal DC. 2013. Food Animals. In: Textbook of Elements of veterinary public health. Pp. 142-143.

Singh VK, Jain U, Yadav JK and Bist B. 2014. Assessment of bacterial quality of raw meat samples (carabeef, chevon, pork and poultry) from retail meat outlets and local slaughter houses of Agra Region. Indian Journal of foodborne and zoonotic diseases. 2(1): 15-18.

Wang JP, Yeh KS, Hsieh MW, Fang CY, Chen ZW and Lin JH. 2013. Pathogenic microbiological baseline survey of pork carcasses in Taiwan. Journal of Food Protection. 76(6): 1046-1050.

Yucel N, Citak S and Onder M. 2005. Prevalence and antibiotic resistance of Listeria species in meat products in Ankara, Turkey. Food Microbiology. 22: 241-245.

\section{How to cite this article:}

Pankaj Mangal, Rakesh Rao and Rajani Joshi. 2018. Assessment of Microbial Load in Raw Pork from Retail Meat Outlets of Bikaner. Int.J.Curr.Microbiol.App.Sci. 7(02): 268-272.

doi: https://doi.org/10.20546/ijcmas.2018.702.035 